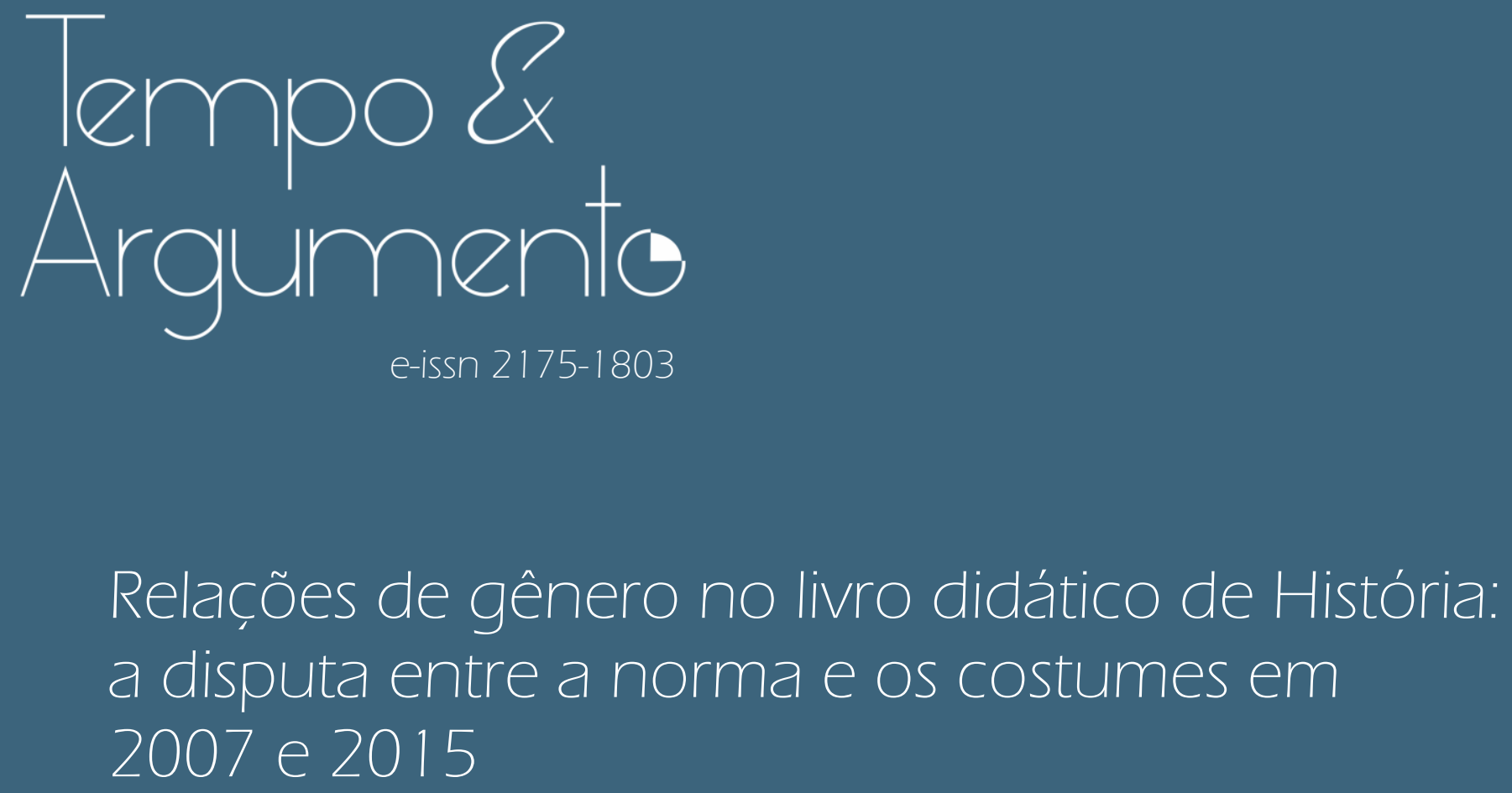

- Allan Alves da Mata Ribeiro

Doutorando em História na Universidade Federal Rural de Pernambuco (UFRPE).

Professor da Secretaria da Educação e da Ciência e Tecnologia da Paraíba.

Recife, PE - BRASIL

lattes.cnpq.br/250969907585547 1

allan_mata@hotmail.com

(D) orcid.org/0000-0003-2799-4941

- Adriana Maria Paulo da Silva

Doutora em História pela Universidade Federal de Pernambuco (UFPE).

Professora da Universidade Federal de Pernambuco (UFPE) e coordenadora do Mestrado profissional em ensino de História (PROFHISTÓRIA/UFPE).

Recife, PE - BRASIL

lattes.cnpq.br/6190925965820163

adrianampsilva@gmail.com

(D) orcid.org/0000-0002-7702-9501

Para citar este artigo:

RIBEIRO, Allan Alves da Mata; SILVA, Adriana Maria Paulo da. Relações de gênero no livro didático de História: a disputa entre a norma e os costumes em

2007 e 2015 . Tempo e Argumento, Florianópolis, v. 12, n. 30, e0205, maio/ago. 2020

doi http://dx.doi.org/10.5965/2175180312302020e0205

Recebido: 29/08/2019

Aprovado: 26/04/2020 


\title{
Relações de gênero no livro didático de História: a disputa entre a norma e os costumes em 2007 e 2015
}

\begin{abstract}
Resumo
Analisamos as concepções de masculinidades e/ou feminilidades presentes na materialidade discursiva de livros didáticos de História endereçados ao Ensino Médio público brasileiro. Enquanto fontes, selecionamos edições distintas da obra "História Global - Brasil e Geral": a edição volume único, aprovada pelo edital do PNLEM/2007; e a coleção didática aprovada pelo edital do PNLD/2015. Em diálogo com Scott (1994, 1995, 1998), Crenshaw (2002, 2012, 2017) e Akotirene (2018), mobilizamos nessa análise o conceito de "modos de endereçamento" (ELLSWORTH, 2001). Advindo dos estudos de cinema e comunicação, o conceito diz respeito ao evento de relação entre o texto fílmico e o lugar social do público. Consideramos que a análise do endereçamento nos livros didáticos de História compreende a observação das estratégias de estruturação e apresentação dos enunciados disponibilizados pelas obras. Concluímos que a abordagem dos conhecimentos históricos adotada pela obra, conforme os costumes, naturalizou assimetrias de poder entre as masculinidades e feminilidades históricas e socialmente construídas. Tomadas enquanto "dado" histórico indigno de nota nos "textos principais", a composição atualizou, no conhecimento histórico escolar, apesar dos regramentos, os posicionamentos costumeiros relativos ao masculino e feminino.
\end{abstract}

Palavras-chave: Livros didáticos - História. Identidade de Gênero. Igualdade na Educação.

\section{Gender relations in the history textbook: the dispute between norm and customs in 2007 and 2015}

\begin{abstract}
We analyzed the conceptions of masculinities and / or femininities present in the discursive materiality of history textbooks addressed to the Brazilian public high school. As sources, we selected different editions of the work "Global History - Brazil and General": the single volume edition, approved by the PNLEM / 2007 notice; and the didactic collection approved by the PNLD / 2015 announcement. In dialogue with Scott (1994, 1995, 1998), Crenshaw (2002, 2012, 2017) and Akotirene (2018) we mobilized in this analysis the concept of "addressing modes" (ELLSWORTH, 2001). Coming from the studies of cinema and communication, the concept concerns the event of relationship between the film text and the social place of the audience. We consider that the analysis of addressing in history textbooks includes the observation of the structuring and presentation strategies of the statements made available by the works. We conclude that the approach to historical knowledge adopted by the work, according to customs, naturalized asymmetries of power between historically and socially constructed masculinities and femininities. Taken as a historical "data" not worthy of note in the "main texts", the composition updated, in school history knowledge, despite the rules, the usual positions regarding the male and female.
\end{abstract}

Keywords: Textbooks - History. Gender identity. Equality in Education.

\footnotetext{
Este artigo resulta da dissertação de mestrado em Educação, intitulada "O Livro didático de História sob a perspectiva das relações de gênero: uma análise entre os anos de 2007 e 2015" defendida em 2018 na Universidade Federal de Pernambuco (UFPE), sob orientação da professora Dra. Adriana Maria Paulo da Silva, com bolsa da Fundação de Amparo à Ciência e Tecnologia de Pernambuco (FACEPE).
} 


\section{0 livro didático de história como objeto de pesquisa}

O livro didático é um dos produtos culturais de maior divulgação entre o público brasileiro com acesso ao ensino escolarizado (FONSECA, 2003, p. 49). Observando a natureza complexa dessas publicações, Circe Bittencourt (2004, p. 296) propôs uma conceituação ampla. Segundo a autora, os materiais didáticos figuram como "mediadores do processo de aquisição do conhecimento, bem como facilitadores da apreensão de conceitos, do domínio de informações e de uma linguagem específica da área de cada disciplina".

Na esteira dessa conceituação, esses materiais podem ser observados em sua relação com as questões curriculares. Em aproximação à teorização proposta por Tomaz Tadeu da Silva (2012), a expressão produtiva do currículo enquanto artefato cultural, atravessado por aspectos sociais e políticos historicamente situados - redimensiona a importância do caráter relacional entre os livros didáticos e as práticas curriculares. Segundo o autor:

As narrativas contidas no currículo, explícita ou implicitamente, corporificam noções particulares sobre conhecimento, sobre formas de organização da sociedade, sobre os diferentes grupos sociais [...]. As narrativas contidas no currículo trazem embutidas noções sobre quais grupos podem representar a si e aos outros e quais grupos sociais podem apenas ser representados ou até mesmo excluídos de qualquer representação. (SILVA, 2012, p. 190)

Ainda segundo o autor, a crítica feminista ao currículo iniciou uma importante mudança epistemológica ao perceber, não apenas as desigualdades que marcam historicamente o acesso aos recursos sociais e educacionais, mas ainda as marcas do gênero na própria epistemologia dominante, instituindo determinados saberes enquanto positivos e desejáveis. Na trama entre saber, subjetivação e poder, o livro didático, assim como o(s) currículo(s) que o constitui(em), pode figurar como um artefato de gênero, "um artefato que, ao mesmo tempo, corporifica e produz relações de gênero." (SILVA, 2005, p. 97).

A História, enquanto campo disciplinar, também produz e põe em circulação determinados saberes a respeito das diferenças sexuais. Segundo a crítica feminista elaborada por Scott (1994, p. 25), a História "faz funcionar [...] um tipo particular de instituição cultural que endossa e publicita construções de gênero". Nesse sentido, se impõe o desafio teórico de uma reflexão voltada não 
apenas à relação entre a experiência feminina e masculina no passado, mas ainda à "conexão entre a história passada e a prática histórica presente" (SCOTT, 1995, p. 74).

Considerando que a instituição escolar e seus materiais didáticos também (re)produzem saberes, posições normativas e desigualdades, analisamos as concepções de masculinidades e/ou feminilidades presentes na materialidade discursiva de livros didáticos de História endereçados ao Ensino Médio público brasileiro. Como fontes principais, definimos duas edições distintas da obra "História Global - Brasil e Geral”, de autoria atribuída a Gilberto Cotrim², sob o selo da Editora Saraiva: a edição volume único, aprovada pelo edital do PNLEM/2007 e publicada em 2005; e a coleção didática publicada em 2013, aprovada pelo edital do PNLD/2015³.

Justificamos a centralidade das diferentes edições da obra "História Global - Brasil e Geral" para nosso estudo tendo em vista esse título ter sido aprovado em todas as edições do Programa Nacional do Livro Didático (PNLD) e Programa Nacional do Livro Didático para o Ensino Médio (PNLEM). Ademais, essa coleção ocupou as primeiras posições nas relações dos títulos mais distribuídos nacionalmente para o componente curricular História4.

Algumas expressões dessa permanência podem ser apreendidas no site do Fundo Nacional do Desenvolvimento da Educação (FNDE). Infelizmente, para a edição do PNLEM/2007, a plataforma não especificou os investimentos por coleção didática. Sabemos, entretanto, que nessa edição foram investidos $R$ \$ 221.540.849,41 para a aquisição de obras didáticas de História e Química, além da reposição de livros de Português, Matemática e Biologia (BRASIL, c2017a).

\footnotetext{
2 Licenciado em História pela Universidade de São Paulo (USP), Mestre em Educação, Arte e História da Cultura pela Universidade Mackenzie e ex-presidente da Associação Brasileira dos Autores de Livros Educativos, gestão 1996/1998 (MUNAKATA, 1997, p. 71).

O "Edital de convocação para o processo de inscrição e avaliação de obras didáticas para o Programa Nacional do Livro Didático PNLD 2015” (BRASIL, 2013, p. 1) compreende por coleção: "[...] o conjunto organizado em volumes, inscrita sob um único e mesmo título, ordenado em torno de uma proposta pedagógica única e de uma progressão didática articulada com o componente curricular do ensino médio".

4 Entre os dados estatísticos dos Programas relativos ao Ensino Médio, especificamente, apenas o PNLD/2012 e PNLD/2015 disponibilizaram uma relação das coleções mais distribuídas por componente curricular. Para outros dados estatísticos: https://www.fnde.gov.br/index.php/programas/programas-do-livro/pnld/dados-estatisticosanos-anteriores. Acesso em: 08 jun. 2020.
} 
Com relação ao PNLD/2015, os dados são mais precisos. Nessa edição do programa, a obra "História Global- Brasil e Geral” figurou em segundo lugar no ranking das edições mais distribuídas nacionalmente, tendo a aquisição de seus três volumes custado pouco mais de 7,4 milhões de reais, somados os valores de aquisição das edições voltadas a alunos e professores (BRASIL, c2017b; c2017c). Considerando que após o PNLD/2015 os dados sobre as coleções mais distribuídas para o Ensino Médio não foram disponibilizados na plataforma, ajustamos nossas análises até essa edição ${ }^{5}$.

Partindo do PNLEM/2008, primeiro a selecionar edições didáticas de História para o Ensino Médio público brasileiro (MELO, 2012, p. 03) ${ }^{6}$, estendemos nossa análise ao PNLD/2015, penúltima edição realizada para o atendimento dessa modalidade de ensino. Ao localizar e relacionar duas edições veiculadas em momentos opostos dos programas nacionais, buscamos identificar rupturas e continuidades nos conteúdos normativos de gênero que perpassam a narrativa das obras avaliadas e aprovadas no âmbito desses programas.

Tendo em vista potencializar o diálogo entre os livros didáticos de História e a produção historiográfica, centramos nossas observações e análises no capítulo “A instituição da República”. Presente nas narrativas sobre o Brasil no final do século XIX, a escolha desse recorte partiu da atenção ao contexto político: emergência da ideia de público e privado, maternidade, privacidade burguesa, e das sempre permanentes, lutas sociais. Enquanto movimento social visível, o Feminismo do século XIX atuou na reivindicação de direitos políticos, sociais e econômicos (GONÇALVES, 2006).

Quanto ao referencial teórico, mobilizamos o gênero enquanto categoria analítica. Pensado com Joan Scott (1995, p. 86), compreendemos as relações de gênero como forma de significar as relações de poder, constituindo um saber a respeito das diferenças sexuais através da significação, variável e historicamente

\footnotetext{
5 Segundo o Guia de livros didáticos do PNLD/2015, dezenove títulos de História foram aprovados nessa edição do Programa (BRASIL, 2014).

- Embora avaliados e aprovados no processo de seleção do PNLEM/2007, os livros didáticos de História foram distribuídos somente a partir de 2008, acompanhados pelo "Catálogo do Programa Nacional do Livro para o Ensino Médio: PNLEM/2008” (BRASIL, 2007). O catálogo dessa edição não divulgou o total de coleções avaliadas, entretanto, dezenove títulos foram aprovados e apresentados.
} 
situada, dessas diferenças - um "saber sobre o corpo" que não pode ser isolado de suas relações numa ampla gama de contextos discursivos (SCOTT, 1994, p. 13).

Nessa perspectiva, nos aproximamos de uma abordagem interseccional. Conceito apresentado pela pesquisadora Kimberlé Crenshaw (2012, 2017), a interseccionalidade opera nas convergências e articulações entre marcadores de gênero, classe e raça, reorientando processos de significação sobre os corpos (AKOTIRENE, 2018, p. 39). Lente analítica elaborada pelo feminismo negro, a abordagem interseccional não institui uma hierarquização, ou constitui somatória, desses marcadores (COLLINS, 2015, p. 17). Segundo Crenshaw:

A interseccionalidade é uma conceituação do problema que busca capturar as consequências estruturais e dinâmicas da interação entre dois ou mais eixos da subordinação. Ela trata especificamente da forma pela qual o racismo, o patriarcalismo, a opressão de classe e outros sistemas discriminatórios criam desigualdades básicas que estruturam as posições relativas de mulheres, raças, etnias, classes e outras. Além disso, a interseccionalidade trata da forma como ações e políticas específicas geram opressões que fluem ao longo de tais eixos, constituindo aspectos dinâmicos ou ativos do desempoderamento. (CRENSHAW, 2002, p. 177)

Por reconhecermos a existência de disputas pela hegemonia dos significados, nos aproximamos ainda do conceito de "modos de endereçamento". Advindo dos estudos de cinema e comunicação, o "modo de endereçamento" diz respeito ao evento de relação entre o texto fílmico e a "posição de sujeito", o lugar social do público, pressuposto a partir das expectativas quanto à recepção dos filmes. Segundo Elizabeth Ellsworth (2001, p. 24), em sua formulação inicial, o conceito parte de uma abordagem dos estudos de cinema interessada em analisar "como o processo de fazer um filme e o processo de ver um filme se tornam envolvidos na dinâmica social mais ampla e em relações de poder".

Concebido inicialmente como um conjunto de estruturas, localizadas no texto fílmico, que buscam uma relação particular entre o texto e seus espectadores, o modo de endereçamento visa a transmissão de determinada comunicação para um "alvo" - uma posição inscrita nas dinâmicas e interesses de poder, uma posição de sujeito, imaginada e endereçada a partir de 
pressupostos sobre o público visado (ELLSWORTH, 2001, p. 15). Inevitavelmente impressos no texto fílmico, tais pressupostos convidam a estabelecer e a compartilhar, ao menos temporariamente, posições sociais e políticas específicas a partir das quais o texto adquire sentido.

Considerando que as obras visaram "endereçar" sua comunicação para determinadas posições de sujeito, compreendemos que partiram de pressupostos inscritos em determinados sistemas de significação historicamente estabelecidos. Nessa trama, problematizamos as escolhas operadas que, ao visibilizarem e valorizarem determinada gama de posições de sujeitos, em detrimento de outras experiências culturais, atuaram reproduzindo e naturalizando relações desiguais de poder, comunicando perspectivas normativas de masculinos e/ou femininos.

Argumentamos que a análise de endereçamento oferece novas compreensões sobre a produção de subjetividades específicas a partir dos livros didáticos de História. Cumpre destacar a contribuição analítica da noção de "currículo oculto", proveniente das análises sociológicas do currículo, ainda nos anos de 1960, e influente para uma leitura crítica sobre as práticas curriculares. Segundo Silva (2005, p. 78), o “currículo oculto” é constituído “[...] por todos aqueles aspectos do ambiente escolar que, sem fazer parte do currículo oficial, explícito, contribuem, de forma implícita, para aprendizagens sociais relevantes". Essas aprendizagens engendram posições dicotômicas e normativas para masculinidades e feminilidades.

Diferentemente de uma abordagem centrada em estruturas ocultas, entretanto, a análise do endereçamento nos livros didáticos de História compreendeu a observação das estratégias de estruturação e apresentação dos enunciados disponibilizados pelas obras. Em sua "aparência”, localizamos uma preocupação "cenográfica” nos livros didáticos de História. Espaço no qual o texto se desenrola, essa cenografia envolve a narrativa e sua apresentação - alinhadas aos aspectos apresentados -, buscando compor um mecanismo de comunicação do currículo para uma posição a partir da qual o texto adquire significado. Envolvidas na comunicação de determinados saberes, essas obras são elaboradas partindo de pressupostos sobre o público desejado. 
Questionamos as composições possíveis e aquelas empenhadas para que os “espectadores” estabeleçam uma determinada relação com o texto.

Quanto à narrativa histórica escolar, inspirados pela crítica de José Batista Neto (1995, p. 100), a recorrência de uma "gramática discursiva" própria aos processos de transmissão desses conhecimentos, buscamos analisar: o tempo narrativo, questionando os possíveis efeitos de sentido de narrativas históricas escolares centradas no passado, a despeito da reflexão sobre as dinâmicas sociais nas quais estão implicadas; a re-inscrição das relações de gênero, relacionada a outros marcadores sociais, como as relações étnico-raciais; e os lugares de produção e reflexão histórica privilegiados pelas narrativas. Componentes de uma "cenografia", tais elementos imprimem significados distintos aos chamados "textos principais", boxes e imagens dos livros didáticos de História.

Visando analisar as estratégias de endereçamento desenvolvidas nas diferentes edições selecionadas da obra "História Global - Brasil e Geral", metodologicamente, "esquadrinhamos" nossa leitura da obra: diante da "cenografia" desenvolvida nos capítulos, identificamos e analisamos os possíveis sentidos de leitura expressos nos textos e imagens constituintes da comunicação. Consideramos que, na observação dos componentes da obra, as legendas laterais auxiliaram a precisar os elementos em destaque durante o desenvolvimento das análises.

\section{Os documentos normativos para elaboração de livros didáticos}

Segundo Kazumi Munakata (2012, p. 59), o livro didático e a escola mantêm uma relação "simbiótica". O autor argumentou que a constituição e expansão dos sistemas públicos de ensino foram acompanhadas, de forma variável e historicamente situada, pela aquisição de obras didáticas por parte do Estado. No contexto brasileiro, essas transações são mediadas pelo Programa Nacional do Livro Didático (PNLD)7.

\footnotetext{
7 Instituído pelo Ministério da Educação (MEC), o decreto no 91.542, de 19/08/1985, estabeleceu as Diretrizes Operacionais para o Programa do Livro didático - 1o grau (1985/86), sob a responsabilidade da Fundação de Assistência Escolar (FAE), criada em 1983 (MUNAKATA, 1997, p. 48).
} 
Institucionalizado em 1985, o PNLD determinou, a partir de 1996, a avaliação prévia das obras didáticas. No âmbito do Ensino Médio público brasileiro, inicialmente, coube ao antigo Programa Nacional do Livro Didático para o Ensino Médio (PNLEM), implantado experimentalmente em 2004, a avaliação e distribuição das obras ${ }^{8}$. Tendo em vista a seleção das obras pelo PNLD e PNLEM, as editoras buscam atender as exigências governamentais traduzidas pelos Parâmetros Curriculares Nacionais (PCN), Diretrizes Curriculares Nacionais (DCN) e as determinações específicas de cada edital dos programas do livro didático (MUNAKATA, 2012, p. 12).

Observamos os Editais do Programa Nacional do Livro Didático, voltados ao Ensino Médio, correspondentes às edições de 2008 e 2015. Investigamos, sob a perspectiva das relações de gênero, quais parâmetros legislativos, curriculares e sociopolíticos figuraram enquanto critérios avaliativos dos livros didáticos de História selecionados para essa análise. Argumentamos que essas normativas expressaram, não apenas a permanência de determinados valores prevalentes em outros tempos, também o propósito de inscrever determinados significados às práticas sociais (VIANNA; UNBEHAUM, 2004).

Tendo em vista que os livros didáticos de História foram elaborados partindo de pressupostos sobre o público desejado - pressupostos inscritos nas obras, atravessados por interesses e expectativas de determinada comunicação com o público -, buscamos indícios da "estrutura de endereçamento" constituída das escolhas possíveis e realizadas na composição das obras. Questionando as composições possíveis e aquelas empenhadas para que o "público" estabeleça determinada relação com o texto, compreendemos que a análise de endereçamento ofereceu uma perspectiva sobre a produção de saberes a partir dessas obras.

\subsection{Edital do PNLEM/2007}

Tendo por objetivo "a convocação de titulares de direito à autoria para a inscrição no processo de avaliação e seleção de livros didáticos, em coleção ou

\footnotetext{
${ }^{3}$ Criado a partir da Resolução no 38 do FNDE, o programa visou atender de forma progressiva todas as séries do Ensino Médio brasileiro. No caso dos livros didáticos de História, por exemplo, somente a partir de 2008 foi iniciada pelo PNLEM a distribuição nacional das obras (MELO, 2012. 16).
} 
Volume Único" (BRASIL, 2005, p. 1), o Edital do Programa Nacional do Livro Didático para o Ensino Médio (PNLEM/2008) definiu as etapas do processo de triagem e avaliação, antecedendo a composição do catálogo, posteriormente intitulado "Guia", de apresentação e divulgação das obras aprovadas.

Segundo determinação do Edital, coube à Secretaria de Educação Básica (SEB/MEC) a realização de uma triagem, por meio da qual as obras seriam avaliadas em sua composição técnica e por seus conteúdos pedagógicos, cujos critérios foram definidos pelo Anexo IX do documento (BRASIL, 2005, p. 9). Nesse anexo, intitulado "Princípios e critérios para a avaliação de obras didáticas para o Ensino Médio de Língua portuguesa e Literatura, Biologia, Física, Química, Matemática, Geografia e História”, despontam os pressupostos avaliativos empregados na seleção, ordenados em categorias gerais. Destacamos: "critérios comuns", voltados a todas as publicações e subdivididos entre "critérios eliminatórios e de qualificação"; e os "critérios para a avaliação de obras didáticas de Ciências Humanas e suas Tecnologias", especificamente no que tangem à disciplina História.

Como "critérios eliminatórios", além da observância aos preceitos legais e jurídicos - Constituição Federal (CF/1988), Estatuto da Criança e do Adolescente (ECA), Lei de Diretrizes e Bases da Educação Nacional (LDB/1996), Diretrizes Curriculares Nacionais do Ensino Médio -, o documento estabeleceu e discutiu três princípios: a) correção e adequação conceituais e correção das informações básicas; b) coerência e pertinência metodológicas; c) preceitos éticos (BRASIL, 2005, p. 36).

Voltando nossa atenção aos preceitos éticos, o edital versou sobre a obrigatoriedade de as obras didáticas atuarem para a construção ética necessária ao exercício da cidadania. Nesse sentido, o texto definiu a exclusão da obra que: a) privilegiasse um determinado grupo, camada social ou região do país; b) veiculasse preconceitos de origem, cor, condição econômico-social, etnia, gênero, orientação sexual, linguagem ou qualquer outra forma de discriminação; c) divulgasse matéria contrária à legislação vigente para a criança e o adolescente, no que diz respeito a fumo, bebidas alcoólicas, medicamentos, drogas e armamentos, entre outros; d) fizesse publicidade de artigos, serviços ou organizações comerciais, salvaguardada, entretanto, a exploração estritamente 
didático-pedagógica do discurso publicitário; e) fizesse doutrinação religiosa; f) veiculasse ideias desrespeitosas ao meio ambiente (BRASIL, 2005, p. 37).

Tais elementos foram reiterados durante todo o documento. Ao direcionar sua atenção aos critérios de qualificação, cujo objetivo foi estabelecer uma distinção entre as obras avaliadas, o edital destacou as edições para a construção escolar da cidadania. Indo para além do "texto-base", o documento versou ainda sobre os preceitos éticos nos aspectos gráficos-editoriais. Segundo o documento, cumpria as ilustrações que:

[...] auxiliem na compreensão e enriqueçam a leitura do texto, devendo reproduzir adequadamente a diversidade étnica da população brasileira, não expressando, induzindo ou reforçando preconceitos e estereótipos. Essas ilustrações devem ser adequadas à finalidade para as quais foram elaboradas e, dependendo do objetivo, devem ser claras, precisas, de fácil compreensão, podendo, no entanto, também intrigar, problematizar, convidar a pensar, despertar a curiosidade. (BRASIL, 2005, p. 38)

Após a observação dos critérios gerais, os critérios de avaliação por área de produção do conhecimento no Ensino Médio - ancorados na Lei de Diretrizes e Bases e nas Diretrizes Curriculares Nacionais para o Ensino Médio estabeleceram os princípios e finalidades na orientação da formação na Área das Ciências Humanas e suas Tecnologias. Tendo em vista especificamente o ensino de história, o texto estabeleceu enquanto principal objetivo, reafirmando elementos anteriores no documento, a formação dos estudantes para a cidadania. Foi definido o papel auxiliar da obra didática para a "compreensão ativa" da realidade, tida como pressuposto para a atuação cidadã. Segundo o texto:

A adequação da obra didática aos objetivos do Ensino Médio supõe um complexo mecanismo de articulação entre, de um lado, os saberes socialmente construídos no processo do conhecimento científico e, de outro, os conteúdos e objetivos do ensino e da aprendizagem escolar. Os conhecimentos advindos da pesquisa dos especialistas não se opõem aos conteúdos que fazem parte do currículo escolar. Este, por sua vez, é uma parcela significativa do saber escolar, que é construído no e para o espaço da escola. A experiência e as representações de mundo e de história que são elaboradas pelos alunos e professores dão as possibilidades de uma reelaboração contínua e criativa do conhecimento que é produzido pelos historiadores. (BRASIL, 2005, p. 62) 
Com base nesses elementos, o documento estabeleceu, mais uma vez, critérios eliminatórios e de qualificação. Divididos em vários subitens, o documento explorou os "critérios eliminatórios" em quatro níveis: a) correção dos conceitos e das informações básicas, atentando aos erros conceituais "mais comuns", como anacronismo, voluntarismo e nominalismo; b) coerência e adequação metodológicas, atentando às estratégias pedagógicas concebidas e aplicadas pelas obras; e c) preceitos éticos (BRASIL, 2005, p. 63). Quanto a este último item, o edital estabeleceu: a) não veicular, nos textos e nas ilustrações, preconceitos que levem a discriminações de qualquer tipo (origem, etnia, gênero, religião, idade ou quaisquer outras formas de discriminação); b) não ser instrumento de propaganda ou doutrinação religiosa; c) despertar para a historicidade das experiências sociais, trabalhando conceitos, habilidades e atitudes, na construção da cidadania; d) estimular o convívio social e o reconhecimento da diferença, abordando a diversidade da experiência humana e a pluralidade social, com respeito e interesse; e) desenvolver a autonomia de pensamento, o raciocínio crítico e a capacidade de argumentar (BRASIL, 2005, p. 66).

Na sequência, o documento explorou os "critérios de qualificação" mobilizados na avaliação das obras. Dentre os pontos abordados pelo texto, destacamos: a) atualização historiográfica e pedagógico-metodológica; b) explicitação da opção metodológica; c) não incorporação, por parte da obra, de “estereótipo como a identificação exclusiva da História a alguns heróis ou a utilização de caricaturas, de períodos ou de personagens, nem a restrição à memória individual ou de grupos" (BRASIL, 2005, p. 67).

Em linhas gerais, podemos observar que o Edital do PNLEM/2007 rompeu o tradicional silêncio quanto às questões de gênero nos documentos e normativas educacionais (VIANNA; UNBEHAUM, 2004). Identificadas como componentes dos preceitos éticos, as abordagens relativas às relações de gênero e sexualidade constituíram os "critérios de eliminação" e de "qualificação" na avaliação dos livros didáticos de todas as áreas e componentes curriculares. 


\section{2 Edital do PNLD/2015}

A exemplo do Edital do PNLEM/2007, o Edital do Programa Nacional do Livro Didático (PNLD/2015) apresentou as etapas de avaliação pedagógica das obras. As principais modificações presentes nesse edital, em relação ao anterior, encontram-se no Anexo III, intitulado "Princípios e critérios para a avaliação de obras didáticas destinadas ao Ensino Médio” (BRASIL, 2013, p. 37).

Partindo da explicitação do artigo 35 da LDB (Lei 9394/96) sobre as finalidades do Ensino Médio 9 , o Edital chamou a atenção para a responsabilidade da escola na formação dos estudantes - reconhecendo o seu "pertencimento à juventude", além de seu protagonismo nas "cenas sociais significativas e relevantes para a vida social, cultural, política e econômica do País, por meio de movimentos estudantis, movimentos culturais, reivindicações próprias [...]." (BRASIL, 2013, p. 37).

Sugerindo o estabelecimento do diálogo com as "culturas juvenis", o documento indicou que "a cultura socialmente legitimada e predominantemente letrada de que a escola é, ao mesmo tempo, porta-voz e via de acesso, não deve se impor pelo silenciamento das culturas juvenis [...]." (BRASIL, 2013, p. 38). É nesse perfil "dialógico" que o documento compreendeu uma estratégia de superação dos desafios da escola no Ensino Médio.

Versando ainda sobre o perfil do aluno, o Edital estabeleceu considerações sobre a adolescência e a sexualidade da seguinte maneira:

Por fim, é preciso considerar que esse jovem se encontra, do ponto de vista do seu desenvolvimento, num momento também particular: a adolescência. Marcada pelo impacto psicológico e existencial decorrente da irrupção da sexualidade, assim como pelas transformações corporais inerentes ao processo de maturação, a adolescência é um momento decisivo da formação

\footnotetext{
${ }^{9}$ No qual lê-se: "O ensino médio, etapa final da educação básica, com duração mínima de três anos, terá como finalidades: I - a consolidação e o aprofundamento dos conhecimentos adquiridos no ensino fundamental, possibilitando o prosseguimento de estudos; II - a preparação básica para o trabalho e a cidadania do educando, para continuar aprendendo, de modo a ser capaz de se adaptar com flexibilidade a novas condições de ocupação ou aperfeiçoamento posteriores; III - o aprimoramento do educando como pessoa humana, incluindo a formação ética e o desenvolvimento da autonomia intelectual e do pensamento crítico; IV - a compreensão dos fundamentos científico-tecnológicos dos processos produtivos, relacionando a teoria com a prática, no ensino de cada disciplina" (BRASIL, 2013, p. 37).
} 
pessoal. Além do trabalho de (re)conhecer-se num novo corpo, o adolescente tem pela frente uma série de alternativas e, mesmo, desafios aos quais será preciso dar respostas satisfatórias, tanto em termos sociais quanto no que diz respeito às suas próprias demandas. Razão pela qual ele se encontra diante de grandes tensões e conflitos, geradores de ansiedade e de instabilidade emocional. Em decorrência, o que caracteriza esse sujeito é uma incessante busca de definições, um intenso e permanente trabalho ético, de (re)construção da própria personalidade, de sua identidade e de suas relações, tanto com os seus grupos de socialização imediata quanto com as representações que consiga elaborar sobre a sociedade em que vive. (BRASIL, 2013, p. 38)

Após tecer considerações sobre o papel da escola e o perfil do alunado em sua "condição juvenil" (BRASIL, 2013, p. 37), o edital apresentou os "critérios de avaliação", articulados entre critérios eliminatórios comuns a todas as áreas e os específicos a cada área e componente curricular. Entre os eliminatórios comuns, o Edital do PNLD 2015 destacou:

1) respeito à legislação, às diretrizes e às normas oficiais relativas ao ensino médio; 2) observância de princípios éticos necessários à construção da cidadania e ao convívio social republicano; 3) coerência e adequação da abordagem teórico-metodológica assumida pela obra no que diz respeito à proposta didáticopedagógica explicitada e aos objetivos visados; 4) respeito à perspectiva interdisciplinar na apresentação e abordagem dos conteúdos; 5) correção e atualização de conceitos, informações e procedimentos; 6) observância das características e finalidades específicas do manual do professor e adequação da obra à linha pedagógica nela apresentada; 7) adequação da estrutura editorial e do projeto gráfico aos objetivos didático pedagógicos da obra; 8) pertinência e adequação do conteúdo multimídia ao projeto pedagógico e ao texto impresso. (BRASIL, 2013, p. 39)

Notamos aqui pontos de aproximação e aprofundamento em relação ao Edital do PNLEM/2007. Voltando nossa atenção aos princípios éticos e democráticos para a construção da cidadania, por exemplo, o edital reiterou o critério de exclusão de obras que “[...] veicularem estereótipos e preconceitos de condição socioeconômica, regional, étnico-racial, de gênero, de orientação sexual, de idade ou de linguagem, assim como qualquer outra forma de discriminação ou de violação de direitos [...]." (BRASIL, 2013, p. 40). 
Quanto aos critérios específicos para a área das ciências humanas, o Edital do PNLD/2015 elaborou uma relação das competências fundamentais para a produção do conhecimento nas disciplinas Filosofia, Geografia, História e Sociologia, cujos objetos comuns identificados seriam "as sociedades humanas em suas múltiplas relações" (BRASIL, 2013, p. 50). No caso da disciplina História, o Edital salientou as diretrizes que deveriam orientar o ensino e a produção didática que o acompanham, no âmbito da renovação historiográfica e redefinição das atividades pedagógicas. Segundo o Edital, caberia ao ensino de História:

1) desestruturar perspectivas históricas eurocêntricas, etnocêntricas, monocausais e cronológico-lineares; 2) superar métodos e práticas pautados na memorização, no verbalismo e na expectativa de dar conta de um vasto repositório de conteúdos factuais; 3) avançar para além da chamada "falsa renovação" que apenas dá nova roupagem a antigas e obsoletas práticas, com a incorporação superficial de diferentes linguagens. Entende-se, assim, que a história escolar deve favorecer a que os estudantes analisem diferentes situações históricas em seus aspectos espaço-temporais e conceituais, promovendo diversos tipos de relações, pelas quais seja possível estabelecer diferenças e semelhanças entre os contextos; identificar rupturas e continuidades no movimento histórico e, principalmente, situar-se como sujeito da história, porque a compreende e nela intervém. (BRASIL, 2013, p. 51)

Em linhas gerais, o Edital redimensiona a importância da análise dos saberes enunciados nos livros didáticos. Meios de comunicação poderosos, os livros didáticos são posicionados enquanto instrumentos cuja comunicação é considerada produtiva para a construção de valores democráticos e de cidadania. Nesse sentido, a participação do espaço escolar, em especial no Edital do PNLD/2015, também é uma dimensão que passa a ser considerada na construção e reposicionamento dos papéis sociais dos "sujeitos da educação".

Para analisarmos a "situação comunicativa" na qual os livros didáticos de História foram introduzidos, partindo das normatizações previstas nos Editais analisados, indagamos: quais foram as escolhas operadas pelos produtores dos textos didáticos selecionados? Considerando os jogos do mercado editorial, em que momento é posto em operação um conjunto de pressupostos distintos das prescrições dos editais? Trata-se apenas de reprodução inconsciente ou há uma 
escolha orientada? Observando esses impressos como produtivos na veiculação de determinados saberes e nos processos de subjetivação no âmbito da vivência escolar, de que formas contribuem para a produção de "posições de sujeito" generificadas? Para este artigo, definimos como fonte o capítulo "A instituição da república", presente em edições distintas da obra "História Global - Brasil e Geral”, aprovada pelos editais do PNLEM/2007 e do PNLD/2015.

\section{Esquadrinhando "A instituição da república” e as relações de gênero nos livros didáticos de História}

\subsection{Edição 2005}

Partimos dos elementos que constituíram a "abertura" do capítulo. Metodologicamente, empreendemos um “esquadrinhamento" da página, visando identificar e analisar os possíveis sentidos de leitura expressos em seus elementos constituintes (Imagem 1). Nessa perspectiva, identificamos uma “cenografia”, compreendida, em nossa análise, enquanto indício da estrutura de "endereçamento" da comunicação. Destacamos: lead, texto principal, imagem e legenda.

Recurso dos gêneros noticiosos, o lead corresponde aos "valores de relevância" atribuídos pelo enunciador na constituição do tema a ser abordado pelo texto. Como destacado por Maria Angélica Lauretti Carneiro (2004, p. 111), este recurso pode operar como um sinal "para que façamos deduções sobre a informação mais importante do texto que nele está sendo sumarizada ou destacada”.

Partindo da análise dos "valores de relevância" estabelecidos, buscamos problematizar a reiteração de papéis sociais normativos para homens e mulheres na produção de determinados conhecimentos históricos em materiais didáticos. Assim, foi possível levantar questões sobre quais saberes têm seu estatuto reconhecido e, talvez mais importante, quais saberes foram marginalizados. 
Imagem 1 - Abertura do capítulo "A instituição da república” (adaptado)

\section{CAPITULO 43}

\section{A instituição da república}

\begin{tabular}{|c|c|}
\hline 岕 & $\begin{array}{l}\text { Nignifica governo da coisa do povo, da coisa pública, do bem comum. No final } \\
\text { do século XIX, a monarquia caíra no Brasil e, em seu lugar, foi implantada a } \\
\text { república. O país mudava a forma de governo sem revolucionar a sociedade: } \\
\text { trocava de bandeira, separava a Igreja do Estado, fazia uma nova Constituição, } \\
\text { tudo no clima de ordem que interessava às elites. } \\
\text { No Brasil, quando foi estabelecida, a república significou "governo da coisa do } \\
\text { povo"? Foi construída com participação popular ou excluiu o envolvimento } \\
\text { do povo no governo? }\end{array}$ \\
\hline 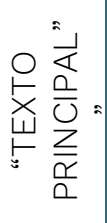 & 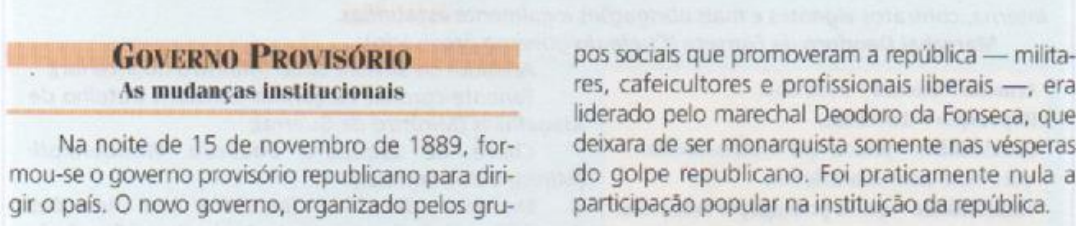 \\
\hline 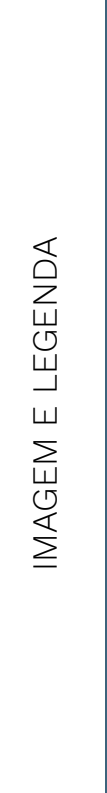 & 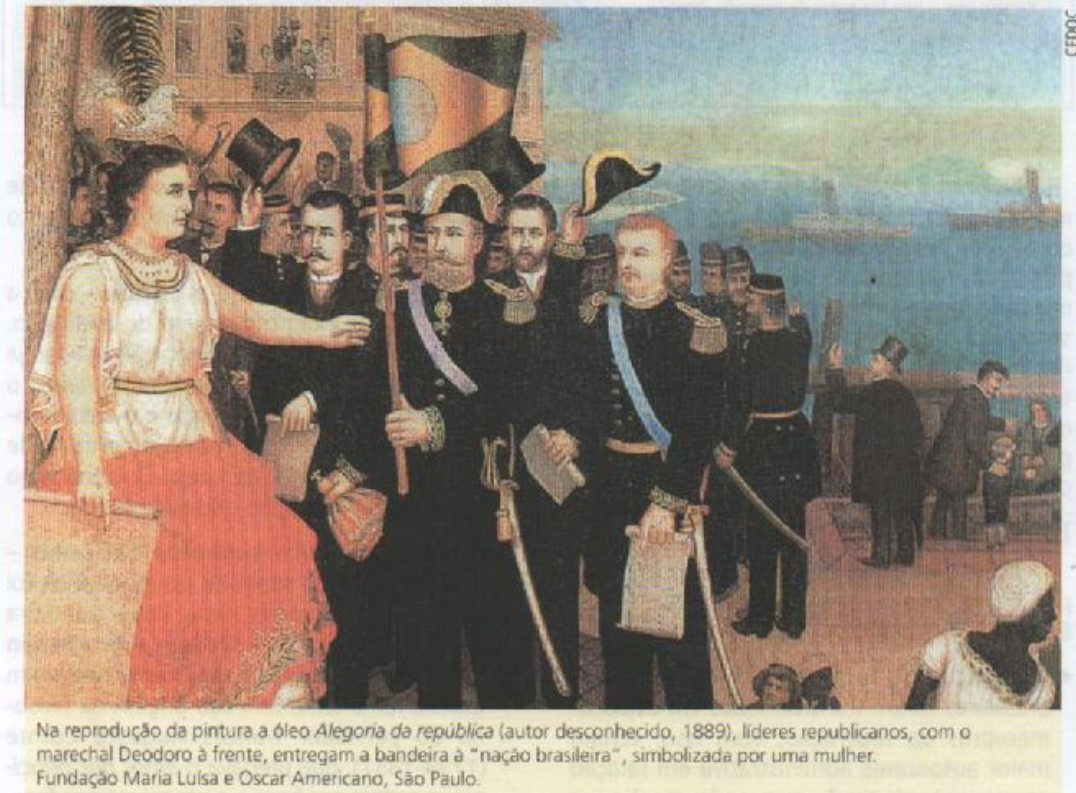 \\
\hline
\end{tabular}

$\underline{405}$

Fonte: COTRIM, 2005, p. 405.

Partindo da definição do conceito de república - elaborada em oposição ao regime monárquico brasileiro e sintetizada como "governo da coisa do povo, da coisa pública, do bem comum” (COTRIM, 2005, p. 405) -, consideramos que é na afirmação seguinte que o lead informou a possível questão central do capítulo, implícita na problematização localizada em seu encerramento: ao afirmar que o "país mudava a forma de governo sem revolucionar a sociedade", constituiu-se a 
incoerência entre "o governo da coisa do povo" e o "clima de ordem que interessava às elites”.

Tal "incoerência" foi objeto de atenção já no primeiro parágrafo do "texto principal”. Iniciando o tópico "Governo Provisório - As mudanças institucionais", a narrativa localizou o tempo e as personagens principais da cenografia apresentada, afirmando objetivamente: na articulação do governo republicano a partir de 1889, liderada pelo marechal Deodoro da Fonseca (1827-1892) e organizada por "militares, cafeicultores e profissionais liberais", a participação popular foi "praticamente nula" (COTRIM, 2005, p. 405).

Constituindo a cenografia, entretanto, sem dialogar explicitamente com a narrativa, destacamos a reprodução da pintura identificada como "Alegoria da república"10:

Imagem 2 - "Alegoria da república" (adaptado)

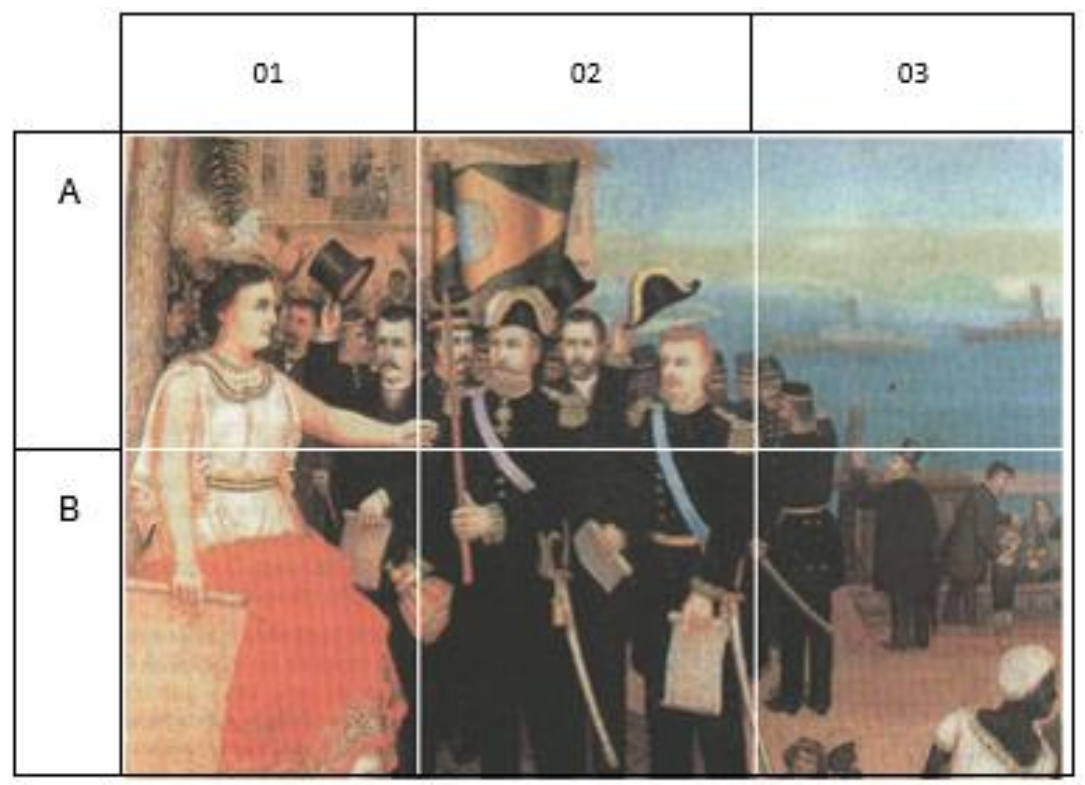

Fonte: COTRIM, 2005, p. 405.

Segundo a legenda disponibilizada:

Na reprodução da pintura a óleo Alegoria da república (autor desconhecido, 1889), líderes republicanos, como o marechal Deodoro à frente, entregam a bandeira à "nação brasileira", simbolizada por uma mulher. Fundação Maria Luísa e Oscar Americano, São Paulo. (COTRIM, 2005, p. 405)

\footnotetext{
10 ALEGORIA à Proclamação da República e à partida da família imperial. 18--. 1 gravura. Disponível em: http://www.faap.br/destaques/constituicoes/07.html. Acesso em: 1 jul. 2018.
} 
Diante da ausência de problematização por parte do texto, o diálogo historiográfico, atento às relações de gênero e história das mulheres, possibilitou levantar algumas questões.

Como destacou José Murilo de Carvalho (1990, p. 75), de inspiração romana, figurando como símbolo da liberdade, a imagem feminina passou a ser mobilizada no debate político francês já em 1792, momento de proclamação da Primeira República francesa. Também a Segunda República, em 1848, reinscreveu a simbólica figura feminina. Elemento marcante no imaginário republicano, inspirado na tradição clássica, a alegoria republicana feminina também encontrou expressão no debate político brasileiro no século XIX.

Diferentemente da famosa criação de Eugène Delacroix, La liberte guidant le peuple, aux barricades, alegoria da insurreição de julho de 1830, a "Alegoria da república” observada no capítulo não ostenta a postura belicosa de liderança: aparentemente sentada (B01; A01) - à semelhança da obra “A República” (1848), de Honoré Daumier - e vestida seguindo a inspiração clássica, a personagem estende a mão para receber, do Marechal Deodoro acompanhado por outros "líderes republicanos", o principal símbolo do novo regime político (A02; B02) ${ }^{11}$.

Merece destaque ainda a mobilização da alegoria em um contexto de impedimento da participação feminina nas decisões políticas, impedimento esse que não ocorreu sem resistências. Historiografando o feminismo no Brasil, Céli Pinto (2003, p. 16) identificou que algumas vozes do feminismo brasileiro, inicialmente advindas dos grupos políticos hegemônicos, brancos e em sintonia com os modelos observados na Europa, despontaram em meio às contradições da república oligárquica.

Voltando sua atenção à França do século XIX, Michelle Perrot (1998) destacou determinado "superinvestimento" do imaginário simbólico masculino nas representações do feminino ideal. Segundo a autora:

Inexistente no nível político, forte mas contido dentro da família, - lugar das mulheres no século XIX é extremo, quase delirante no imaginário público e privado, seja no nível político, religioso ou

\footnotetext{
${ }^{11}$ Para uma análise da veiculação e dos limites na recepção de alguns dos principais símbolos mobilizados pelos principais grupos republicanos brasileiros, notadamente, o positivista, ver: CARVALHO, José Murilo de. A formação das almas: o imaginário da República no Brasil. São Paulo: Companhia das Letras, 1990.
} 
poético. A Igreja celebra o culto da Virgem Maria, cujas aparições geram grandes peregrinações. Os saint-simonianos sonham com a salvação por obra da Mãe, vinda do Oriente. A república encarnase numa mulher, a Marianne. Poetas e pintores cantam a mulher, na mesma proporção de sua misoginia cotidiana. (PERROT, 1998, p. 182)

A articulação das relações de gênero a outros marcadores sociais de diferença também mereceu destaque. Embora, em comparação ao gênero, classe e raça não apresentem estatutos equivalentes ${ }^{12}$, a disposição das personagens na cena poderia servir de ponto de partida para o questionamento das desigualdades sociais firmadas no contexto político representado. No extremo oposto à figura idealizada - quase ocultada pelo recorte empreendido na imagem -, "outra" feminilidade, acompanhada por duas crianças que parecem observar os acontecimentos em primeiro plano, ocupou a cena (B03), informando sobre as desigualdades de poder articuladas aqui em, ao menos, três eixos (SCOTT, 1995).

Quanto às masculinidades, salientamos o primeiro plano da imagem: os “líderes republicanos", tendo Deodoro à frente, reverenciam a alegoria do regime republicano. Além dos representantes militares, destacados através da indumentária dos personagens centrais à pintura (A02; B02), lideranças civis também acompanham a reverência (A01; A02). Nossa atenção recaiu ainda para o gesto de entrega da bandeira nacional à alegoria: realizado por Deodoro enquanto segura, com a mão direita, a coroa, símbolo do poder imperial (B01).

Em contraste ao poder que esse personagem inspira, ao fundo da imagem, outras masculinidades parecem deixar a cena. Gesticulando em direção ao Palácio, talvez o Paço de São Cristóvão, uma figura idosa guarda semelhança com próprio D. Pedro II, seguido por seu genro, o conde D’Eu. Este último acompanha uma criança em direção a uma figura feminina, aparentemente sentada na embarcação ao fundo da pintura, possivelmente Luís (nascido em 1878), ou

\footnotetext{
${ }^{12}$ Como destacou Scott: "Enquanto a categoria "classe" tem seu fundamento na elaborada teoria de Marx [...] sobre a determinação econômica e a mudança histórica, "raça" e "gênero" não carregam associações semelhantes [...] Quando invocamos a classe, trabalhamos com ou contra uma série de definições que, no caso do marxismo, implicam uma ideia de causalidade econômica e uma visão do caminho ao longo do qual a história avançou dialeticamente. Não existe nenhuma clareza ou coerência desse tipo para a categoria de raça ou para a de gênero" (SCOTT, 1995, p. 73).
} 
Antônio (nascido em 1881), seguindo ao encontro de sua mãe, de D. Isabel, no extremo oposto à alegoria (B03) -ocupando um plano superior apenas em relação à mulher e às crianças negras ao canto e, literalmente, quase "saindo" da cena.

Embora ausente nas considerações do "texto principal", compreendemos que a imagem constituiu um elemento destacado na cenografia do capítulo. Além de restituir o discurso da "exclusão popular" na instituição da República, sob a perspectiva das relações de gênero, a imagem ofereceu indícios sobre os principais agentes na narrativa histórica retratada: as masculinidades compartilhadas nos marcadores de toda a cenografia, "masculinidades agentes", os "militares, cafeicultores e profissionais liberais".

Considerando a especificidade desse grupo, concordamos com a reflexão do sociólogo Michael S. Kimmel (1998) quanto a uma "sobreposição de masculinidades" no século XIX, fundamental à construção de definições "hegemônicas" e "subalternas". Plurais, variando entre as posições de poder visibilizadas, as masculinidades da cenografia encontraram como contraponto, tanto as feminilidades idealizadas - motivo de reverência em um contexto de exclusão da participação na política institucional -, quanto as feminilidades "subalternizadas", no extremo oposto das anteriores, e cuja visibilização questionou os silêncios do "texto principal".

As ações dessas "masculinidades agentes", afinadas à política institucional, configuraram o conjunto hierárquico da composição narrativa, cujas temáticas foram evidenciadas nos tópicos seguintes - "Primeiras providências", "Encilhamento: a especulação financeira" e "A primeira Constituição da república" - e no box, localizado no primeiro tópico e intitulado "Manifesto do novo governo". Essa cenografia endereçou nossa leitura para as ações de um grupo restrito, cuja dominância refletiu no próprio ordenamento narrativo.

No tópico "Primeiras providências", o "texto principal" sintetizou as medidas do governo provisório no processo de reorganização do Estado brasileiro. Dedicando um parágrafo a cada temática, a narrativa apresentou: instituição do federalismo; separação entre Igreja e Estado - dedicando uma linha à instituição do registro civil de nascimento e ao casamento civil, tidos como resultado da extinção do regime de padroado, "por meio do qual o Estado 
controlava a Igreja católica" (COTRIM, 2005, p. 406) -; criação de novos símbolos nacionais, atentando à criação da nova bandeira nacional sob o lema Ordem e Progresso - apenas citado enquanto sugestão do ministro da Guerra Benjamim Constant (1836-1891), em referência à obra de Auguste Comte (1798-1857) -; e a Promulgação da lei da grande naturalização, identificada como resposta ao sentimento "antilusitano de boa parte da população brasileira urbana" (COTRIM, 2005, p. 407).

Na sequência, a narrativa tratou da política econômica, voltando sua atenção à reforma financeira iniciada por Rui Barbosa, a política do Encilhamento. Justificando a nova política econômica no interesse governamental por "estimular o crescimento econômico, principalmente o desenvolvimento da indústria" (COTRIM, 2005, p. 407), o texto seguiu discutindo os processos inflacionário e de especulação financeira resultantes da reforma, levando o então ministro da Fazenda, Rui Barbosa, à demissão do cargo em 1891.

Mereceu maior destaque o tópico seguinte: "A primeira Constituição da república”. Voltado à constituição republicana de 1891, a exemplo da métrica dos tópicos anteriores, cuja "objetividade" reitera a centralidade cenográfica na atuação dos grupos hegemônicos, o texto sintetizou em pequenos parágrafos “alguns de seus tópicos principais" (COTRIM, 2005, p. 408). Foram eles: a adoção do sistema presidencialista de governo, seguida pela transformação política das antigas províncias do Império em estados-membros; a divisão dos poderes em Executivo, Legislativo e Judiciário; e o direito ao voto, estabelecido na exclusão de "analfabetos, mendigos, soldados e religiosos sujeitos à obediência eclesiástica. As mulheres também não podiam votar" (COTRIM, 2005, p. 408).

Em relação a esse último tópico, a edição de 2005 de "História Global Brasil e Geral" dedicou um pouco mais de atenção. Recorrendo à obra "Os bestializados", de José Murilo de Carvalho (1990), o texto reforçou a ideia de exclusão popular das práticas políticas institucionais. Citando o autor e salientando o envolvimento da população da cidade do Rio de Janeiro nas associações e festas populares, a obra destacou que "[...] Negros livres, exescravos, imigrantes, proletários e classe média encontraram aos poucos um terreno comum de auto-reconhecimento que não era propiciado pela política." (CARVALHO, 1987 apud COTRIM, 2005, p. 408). 
Consideramos tal citação um recurso retórico significativo para o argumento central do capítulo. Sob o signo da autoridade conferida ao autor, no caso, José Murilo de Carvalho (1990), a narrativa da "exclusão popular" assumiu um caráter categórico, "amparado" historiograficamente e passível a mudanças apenas futuras: o parágrafo seguinte buscou informar que, somente no decorrer do período republicano, os "seguimentos sociais excluídos" passaram a "lutar pelo direito de voto" (COTRIM, 2005, p. 408). Durante toda a narrativa, esse foi o primeiro momento no qual, aos "excluídos da história", sinalizou-se a possibilidade, ainda que futura, de algum espaço de agência ${ }^{13}$.

Talvez, em reconhecimento aos limites impostos às "agências", à atuação dos sujeitos representados, o texto indicou, na sequência, de forma genérica em curto parágrafo, que, em função das lutas sociais republicanas, “[...] Ao longo do século XX, o voto passou a ser secreto e as mulheres, os religiosos, os analfabetos, assim como os maiores de 16 anos, conquistaram o direito de votar" (COTRIM, 2005, p. 408). Tal abordagem, entretanto, deixou escapar a contradição lógica da exclusão desses grupos sociais em um contexto republicano. Como argumentou Pinto (2003, p. 18), sem explicitar a exclusão das mulheres, a mobilização da carta constitucional de 1891 evidenciou a interpretação dos significados sociais correntes no contexto brasileiro do século XIX: a "natural" exclusão das mulheres na participação política.

Perrot (1988) argumentou que, no contexto posterior à Declaração dos Direitos do Homem e sua suposta declaração de igualdade entre os homens, o discurso de naturalização da exclusão das mulheres da cena política encontrou sua renovação no processo de significação das diferenças sexuais. Em sua perspectiva, ancorado no discurso "naturalista” da medicina e da biologia,

O século XIX acentua a racionalidade harmoniosa dessa divisão sexual. Cada sexo tem sua função, seus papéis, suas tarefas, seus espaços, seu lugar quase predeterminado, até em seus detalhes. Paralelamente, existe um discurso dos ofícios que faz a linguagem do trabalho uma das mais sexuadas possíveis. "Ao homem, a madeira e os metais. À mulher, a família e os tecidos" [...]. (PERROT, 1988, p. 178)

\footnotetext{
${ }^{13}$ Nesse sentido, pensamos com Scott (1995, p. 86) o conceito de agência humana, compreendido como a tentativa "[...] para construir uma identidade, uma vida, um conjunto de relações, uma sociedade estabelecida dentro de certos limites e dotada de uma linguagem - uma linguagem conceitual que estabeleça fronteira e contenha, ao mesmo tempo, a possibilidade de negação, de resistência, da reinterpretação e permita o jogo da invenção metafórica e da imaginação."
} 
Em linhas gerais, embora o "texto principal" não tenha objetivado abordar explicitamente as questões relativas aos papéis sociais desempenhados por homens e mulheres, na cenografia apresentada, predominaram as ações de determinadas masculinidades. Consideramos que, ao reiterar o discurso da "exclusão popular", "endereçado” pelo conjunto cenográfico, o capítulo imprime um caráter "categórico" à exclusão: uma "constatação" autorizada, em última análise, através do discurso historiográfico, referenciado uma única vez no "texto principal”.

Inscritas nesse discurso, as relações de gênero mereceram destaque, notadamente na "Alegoria da república”. Aparentemente autônoma em relação ao "texto principal", a imagem favoreceu tanto uma leitura coerente às questões "de relevância" sumarizadas pelo lead, quanto à observação dos símbolos generificados culturalmente disponíveis. A alegoria feminina da República mobilizada em um contexto de política institucional vedada à participação das mulheres - desempenhou o papel atribuído aos símbolos nacionais, signos de expressão do poder dos personagens que de fato "atuaram" na imagem e no conjunto cenográfico constituído pelo capítulo. A desigualdade de poderes não foi problematizada na narrativa, mais do que a "constatação" da exclusão popular, consideramos que a obra ofereceu uma "reencenação" dessas exclusões, naturalizando-as.

Se pensarmos com Perrot (1988), talvez, tais escolhas expressem a reatualização, na produção de conhecimento no espaço escolar, de um saber sobre a exclusão da atuação de determinados grupos sociais nos espaços da política institucional no mundo ocidental do século XIX. Sob a perspectiva das relações de gênero, concordamos com Scott (1998, p. 304) que a simples visibilidade de marcadores de desigualdade não possibilita a compreensão das práticas e discursos que subjazem sua produção. Ao encerrar a leitura do capítulo, compreendemos que mecanismos de desigualdade existiram, mas não sabemos como estes foram produzidos historicamente - não sendo em nada "naturais" portanto. 
Relações de gênero no livro didático de História: a disputa entre a norma e os costumes em 2007 e 2015

Allan Alves da Mata Ribeiro, Adriana Maria Paulo da Silva

\subsection{Edição 2013}

O capítulo "A instituição da República" presente na edição de 2013 chamou a atenção pela aparente estabilidade em relação ao anterior. Entretanto, a observação dos elementos que constituíram a "abertura" do capítulo anunciou uma possível mudança nos "valores de relevância" do texto (Imagem 3). Buscando investigar os efeitos de sentido dessa reorganização, observamos os componentes cenográficos da abertura:

Imagem 3 - Abertura do capítulo "A instituição da república" (adaptado)

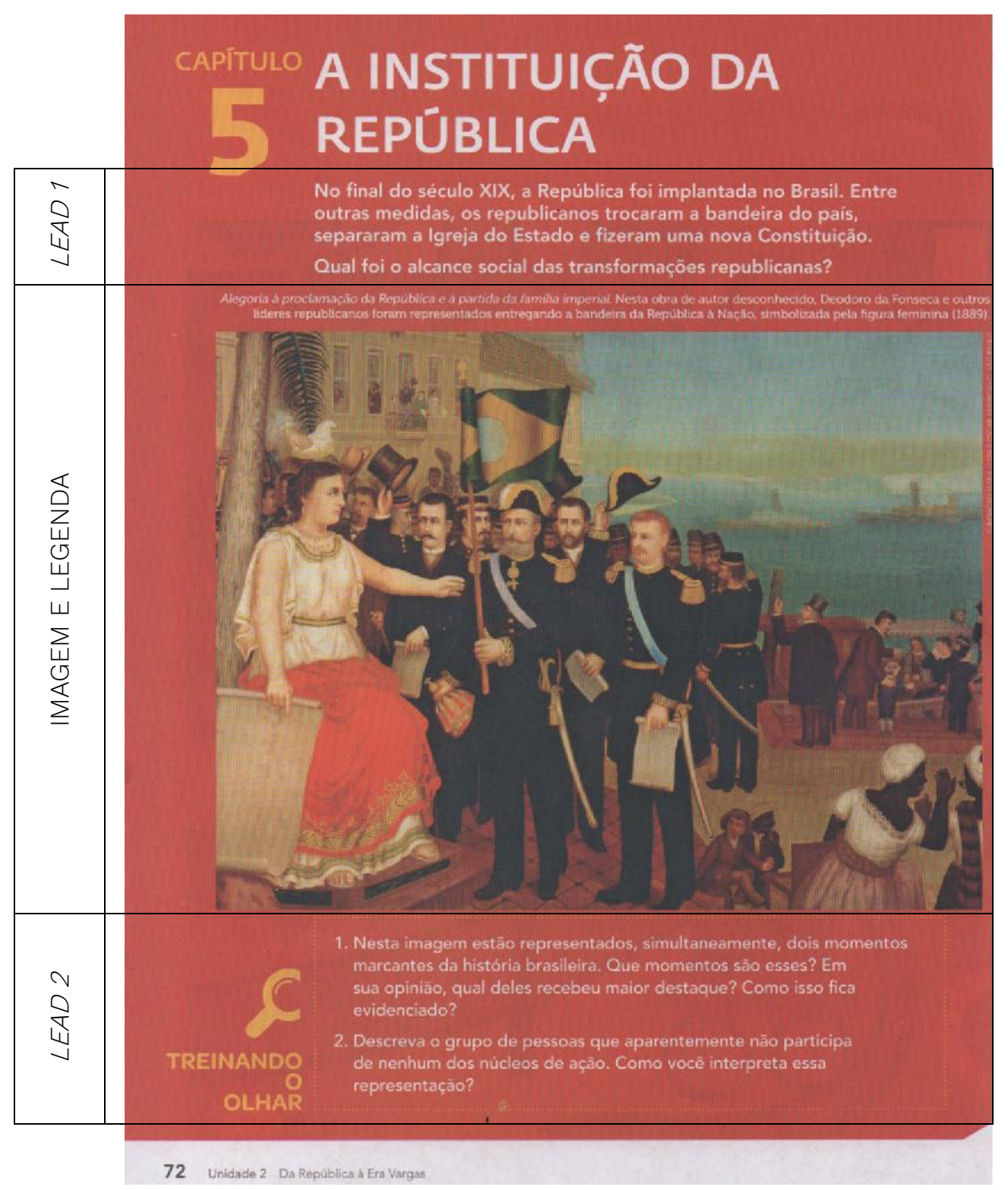

Fonte: COTRIM, 2013, p. 72.

Partindo da listagem objetiva de algumas das medidas que acompanharam a instituição do regime republicano no Brasil, o lead lançou a possível questão 
norteadora do capítulo: "Qual foi o alcance social das transformações republicanas?" (COTRIM, 2013, p. 72).

Operando como recurso complementar ao lead, a abertura apresentou a imagem "Alegoria à proclamação da República e à partida da família imperial”, acompanhada por questões constitutivas da seção "Treinando o Olhar" e, dentre elas, destacamos: “Descreva o grupo de pessoas que aparentemente não participa de nenhum dos núcleos de ação. Como você interpreta essa representação?" (COTRIM, 2013, p. 72). Ao complementar a questão proposta no lead, consideramos que a seção "Treinando o olhar" contribuiu para uma problematização do discurso da "exclusão popular", objeto de debate na edição de 2005.

Ocupando posição central na cenografia da página, a imagem mereceu destaque. Além da mudança no próprio título da obra - identificada anteriormente apenas como "Alegoria da república" (COTRIM, 2005, p. 405) -, a redefinição no recorte da imagem, somada à qualidade da impressão do material, possibilitou outras leituras.

Imagem 4 - "Alegoria à proclamação da República e à partida da família imperial" (adaptado)

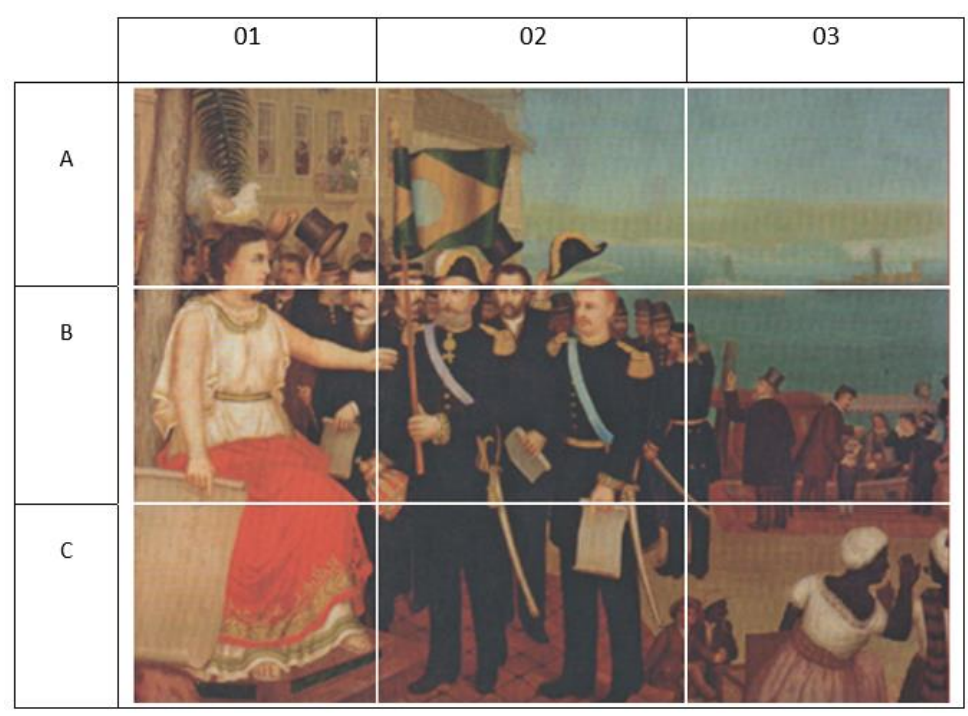

Fonte: COTRIM, 2013, p. 72.

A nova edição permitiu a visualização de alguns elementos ilegíveis na impressão anterior. No canto direito da imagem (B03), notamos a família real, representada no momento de sua partida, em 17 de novembro de 1889. A figura 
de perfil, apontada pelo conde D’Eu, pareceu representar D. Isabel, herdeira do regime prestes a deixar a cena e a política nacional.

Outro elemento em destaque é o objeto que "paira" sobre a alegoria republicana (A01). Retratada em um vestido branco e capa vermelha, a alegoria recebe um barrete frígio branco (e não vermelho, como o ostentado por Marianne) de uma mão que remete à própria "Providência Divina". Como salientado por Joseph Jurt (2012, p. 471), essa representação adiciona uma dimensão "sagrada" à idealização e mitificação dos acontecimentos retratados.

Consideramos ainda que a imagem pareceu estabelecer uma oposição entre sagrado e o profano sugerida na disposição das personagens que dividem, em planos distintos, as margens da pintura: de um lado, a alegoria feminina idealizada e sagrada; do outro, D. Isabel, herdeira do regime anterior. Um pouco abaixo, figuram ainda as "outras" feminilidades "não-sagradas" pela imagem (C03). Esboçando um gesto que sugere o diálogo entre elas, as personagens não parecem, entretanto, alheias aos acontecimentos "retratados" (ou inventados).

Em seu conjunto, consideramos que a composição cenográfica introdutória do capítulo problematiza o discurso da "exclusão popular" na instituição da República. A exemplo da edição anterior, o primeiro parágrafo do "texto principal" retomou a questão destacada na abertura. Para melhor compreensão, reunimos os parágrafos disponibilizados nas duas versões analisadas:

Imagem 5 - Parágrafos seguintes à abertura: à esquerda, o texto constituinte da edição de 2005 (adaptado), seguido, à direita, do parágrafo presente na edição 2013.

Na noite de 15 de novembro de 1889, formou-se o governo provisório republicano para dirigir o pa's. O novo governo, organizado pelos grupos sociais que promoveram a república - miltares, cafeicultores e profissionais liberais - era liderado pelo marechal Deodoro da Fonseca, que debara de ser monarquista somente nas vésperas do golpe republicano. Foi praticamente nula a participacáo popular na instituicăo da republica.
A queda do regime monárquico e a proclamaçăo da República ocorreram num clima de ordem e de concordância entre as elites. Provavelmente, a ideia predominante era mudar a forma de governo sem revolucionar a sociedade brasileira. Por isso, năo houve interesse, por parte das elites, em convocar a populaçâo em geral para participar desse processo.

Num relato que ficou famoso, Aristides da Silveira Lobo, jornalista e ministro do primeiro governo republicano, expressou a ausência popular no dia em que foi proclamada a República, 15 de novembro. Ele conta que, naquela ocasião, o povo assistiu a tudo "bestializado", supondo que estivesse vendo, talvez, uma parada militar.

Fonte: COTRIM, 2005, p. 405; COTRIM, 2013, p. 73. 
Embora comum aos dois textos, o discurso da "exclusão popular" recebeu outro tratamento na edição de 2013. Atenuando o caráter "categórico" da afirmação referente ao texto de 2005 - "Foi praticamente nula a participação popular na instituição da república" (COTRIM, 2005, p. 405) -, na edição de 2013, a não convocação popular figurou como resultante do desinteresse político das elites articuladoras da instituição da república.

Consideramos - a despeito da referência aos "bestializados" feita em seguida (COTRIM, 2013, p. 73) - que esses deslocamentos poderiam sugerir uma redefinição na orientação do "texto principal": de uma análise centrada nas ações de um grupo restrito de agentes para uma abordagem problematizadora das assimetrias de poder marcantes no período descrito. Nessa perspectiva, exploramos as mudanças na cenografia do capítulo que indicassem pistas quanto à abordagem das questões de gênero.

Ironicamente, ao iniciar o tópico "Primeiras providências", acompanhamos o desenvolvimento de uma narrativa que reuniu objetivamente, a exemplo da edição anterior, algumas das "providências" já listadas no lead do capítulo. Compondo a cenografia da página, entretanto, mereceu destaque a imagem "A Pátria”, datada do início do século XX14.

Imagem 6 - "A Pátria” (adaptado)

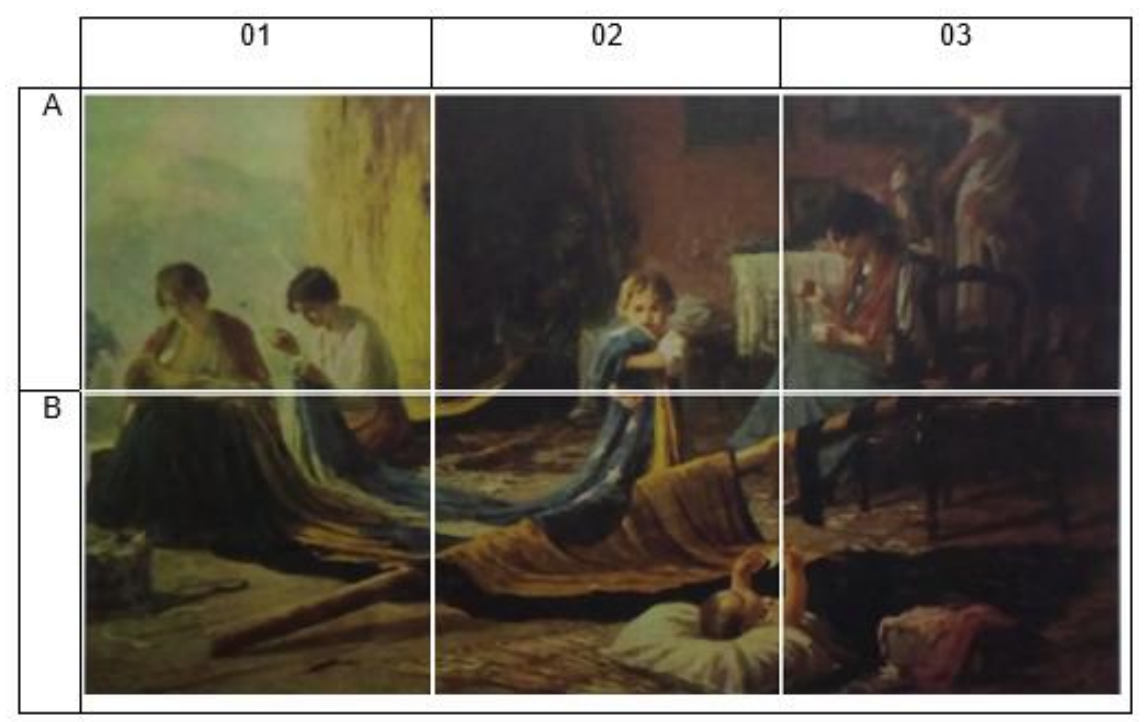

Fonte: COTRIM, 2013, p. 73. 
Acompanhada da legenda "A Pátria, obra de Pedro Bruno, de 1919. A esposa de Benjamin Constant, positivista republicano, foi representada costurando a nova bandeira do Brasil" (COTRIM, 2013, p. 73), a obra operou como importante recurso cenográfico, constituindo junto ao "texto principal", embora ausente em suas considerações, uma narrativa da "criação dos novos símbolos nacionais".

Uma das reproduções mais importantes sobre a bandeira nacional, "A Pátria" é uma composição assinada pelo pintor, escultor e paisagista Pedro Bruno (1888-1949). Atrelados aos símbolos da pátria, a imagem evocou ainda representações simbólicas de gênero e conceitos normativos que permitem interpretações desses símbolos (SCOTT, 1995). Centralizada na criança abraçada à bandeira atribuída a Décio Villares (1851-1931) (A02; B02), a imagem visibilizou ainda a esposa não nomeada de Benjamin Constant, Maria Joaquina Bittencourt Costa (A03) - apresentada em função de seu cônjuge na legenda que acompanhou a imagem.

Para além do contexto das disputas políticas entre os grupos positivistas pelo novo símbolo nacional, "A Pátria" veiculou um dos principais construtos do imaginário masculino sobre as feminilidades no século XIX: a maternidade relacionada ao cuidado do lar, dos filhos e a determinados ofícios considerados domésticos e, portanto, femininos. A esse respeito, salientamos a descrição de Carvalho (1990) dos elementos generificados que constituem a composição. Segundo o autor:

É uma exaltação tanto à bandeira e à pátria quanto ao papel moral da mulher na educação dos filhos e no culto dos valores morais da família e da pátria. O símbolo materno é também óbvio na mulher que amamenta e na outra que abraça e beija uma criança. A presença masculina limita-se a um velho quase escondido no canto direito. O quadro refere-se provavelmente ao fato de terem as filhas de Benjamin Constant bordado uma bandeira positivista, que foi oferecida à Escola Militar. (CARVALHO, 1990, p. 119)

Além disso, enquanto a República, velha conhecida, foi associada a uma mulher, aquela invenção recente, "a Pátria”, podia, ela mesma, ser identificada às crianças pequenas, dependentes das ações das mulheres e do olhar atento e próximo dos homens. Embora coerente quanto ao objeto de atenção do "texto principal”, chamou a atenção a ausência, na narrativa, de considerações quanto 
à imagem. Consideramos que a naturalização das posições normativas de gênero, constitutiva da cenografia, reforçou uma abordagem orientada pela atuação das "masculinidades agentes" no texto. Assim, os tópicos seguintes, "Encilhamento: a reforma financeira" e "Primeira constituição da república", retomaram a abordagem da edição anterior.

Em linhas gerais, a cenografia do capítulo buscou endereçar a leitura para um tratamento semelhante àquele desenvolvido na edição de 2005. Embora a cenografia do capítulo, em princípio, enderece a leitura para uma problematização do que chamamos discurso da "exclusão popular" notadamente através do lead na abertura do capítulo e do parágrafo que the foi consecutivo -, o "texto principal” manteve sua atenção na atuação política dos grupos hegemônicos, responsabilizados pelo "dado" da exclusão. A exemplo da edição anterior, essa abordagem foi reestabelecida através do recurso à citação historiográfica (COTRIM, 2013, p. 75).

As principais mudanças da edição estiveram concentradas no aspecto editorial, imprimindo outras possibilidades analíticas. Para além do alinhamento da narrativa à atuação de uma "masculinidade agente" específica, mereceu destaque a mobilização de imagens marcadas por uma "codificação generificada" (SCOTT, 1995), inscritas na construção simbólica do período republicano brasileiro e reinscritas (reatualizadas e revalidadas) na composição cenográfica do capítulo apresentado. Em uma oposição constitutiva a uma narrativa de poucos agentes, coube às feminilidades apenas a permanência atávica da passividade doméstica, embora sua reinscrição dentre símbolos nacionais.

Ausentes no "texto principal", salientamos que essas imagens poderiam possibilitar a problematização dos símbolos culturalmente disponíveis, das interpretações de sentido desses símbolos e dos agenciamentos políticos para engendrar valores no período republicano. Eloquente na composição cenográfica, consideramos que o silenciamento desses registros pelo "texto principal" endereça posições normativas de gênero, naturalizadas e reinscritas na narrativa histórica escolar. 


\section{Conclusão}

O presente artigo analisou as concepções de masculinidades e/ou feminilidades presentes na materialidade discursiva de livros didáticos de História endereçados ao Ensino Médio público brasileiro. Mobilizamos como fontes duas edições distintas da obra "História Global - Brasil e Geral": a edição volume único, aprovada pelo edital do PNLEM/2007 e publicada em 2005; e a coleção didática publicada em 2013, aprovada pelo edital do PNLD/2015. Presente em todas as edições do Programa Nacional do Livro Didático, a obra foi destacada enquanto uma das publicações mais distribuídas para o componente curricular história no Ensino Médio público brasileiro.

Visando discutir os possíveis efeitos de sentido no evento da relação entre os livros didáticos e o público imaginado e desejado por estas obras, mobilizamos o conceito de “modo de endereçamento" (ELLSWORTH, 2001). Considerando o endereçamento de sua comunicação para determinada posição de sujeito, compreendemos que os livros didáticos de História partem de pressupostos sobre o público visado, pressupostos impressos na materialidade de seus enunciados e inscritos em determinado sistema de significação historicamente estabelecido, transbordando como acontecimento para além do texto.

A composição esquadrinhada e analisada expressou uma cenografia centrada na atuação do que denominamos "masculinidades agentes": masculinidades específicas, cuja atuação e interesses, alinhados à trama das transformações políticas e institucionais no início do período republicano brasileiro, constituíram os principais objetos de atenção. Construindo saberes quanto às dinâmicas de gênero no período descrito, consideramos que o capítulo, através da ausência de considerações nos "textos principais", naturalizou as relações de poder entre masculinidades e feminilidades histórica e socialmente construídas durante o século XIX. Tomadas enquanto "dado" histórico indigno de nota nos "textos principais", a composição atualizou, no conhecimento histórico escolar, posições normativas de ser masculino e feminino.

Isso não significou, entretanto, a criação de uma "história masculina" indefinida. As chamadas "masculinidades agentes", aquelas destacadas pela composição, constituíram posições específicas nas relações de poder, 
atravessadas por questões de raça e classe. Identificadas aos grupos políticos hegemônicos e brancos, essas masculinidades atuaram em oposição às masculinidades subalternizadas, não brancas e marginalizadas na política institucional.

Quando observadas em relação às determinações expressas nos editais do Programa Nacional do Livro Didático, tais abordagens destoam completamente dos critérios assumidos na avaliação das obras. Contrariando as possiveis expectativas formuladas com base na atenção às questões de gênero e sexualidade propostas pelas normativas para a elaboração das obras didáticas, a narrativa do "texto-base" permaneceu centrada na descrição de estruturas econômicas e políticas, nas quais os agentes históricos permaneceram diluídos no interior de categorias sociais aparentemente a-históricas.

Embora a publicação seja bem-sucedida, tanto em relação às avaliações estabelecidas pelos editais que orientam a execução do PNLD, quanto em relação à distribuição das obras relativas ao componente curricular história, o objetivo de promover "reflexão crítica" e "construção da vida cidadã" (BRASIL, 2005; 2013) não foi atendido nas obras analisadas.

Pela perspectiva das relações de gênero, essas "cenografias" construíram posições específicas para as masculinidades e feminilidades representadas. Quando estiveram presentes nos "textos principais", as feminilidades foram "endereçadas", atreladas à passividade doméstica ou circunscritas aos símbolos políticos em contextos vetados à participação feminina. Comunicando saberes alinhados a determinadas concepções de masculinidades, geralmente relacionadas ao poder e às ações "dignas de nota”, os "textos principais" contrapõem imagens ocupadas na visibilização de determinadas feminilidades, figurantes de curta participação numa narrativa que oportuniza uma estreita gama de posições de sujeito.

Acreditamos que analisar o livro didático na perspectiva das relações de gênero, esquadrinhando e alertando as suas cenografias das relações de poder, constitui um importante campo político para a formulação de uma educação comprometida com o igualitarismo e o respeito absoluto às diferenças. Somos esperançosos do exercício de uma história escolar problematizadora das 
estratégias de silenciamento e invisibilidade das diferenças historicamente construídas e fortemente presentes na sociedade brasileira, nas nossas práticas educativas majoritárias e, particularmente, nos materiais didáticos disponibilizados para as escolas públicas no Brasil, a despeito dos vultuosíssimos investimentos públicos no PNLD.

\section{Referências}

AKOTIRENE, Carla. O que é interseccionalidade? Rio de Janeiro: Editora Letramento, 2018.

BATISTA NETO, José. A problemática do ensino da história nos textos e nas imagens dos livros didáticos. Tópicos Educacionais, Recife, v. 13, n.1-2, p. 97-120, 1995.

BITTENCOURT, Circe Maria Fernandes. Ensino de história: fundamentos e métodos. São Paulo: Cortez, 2004.

BRASIL. Ministério da Educação. Fundo nacional de desenvolvimento da educação. [Brasília: Ministério da Educação], c2017a. Disponível em:

http://www.fnde.gov.br/component/k2/item/3010?/temid=1296. Acesso em: 11 ago. 2019.

BRASIL, Ministério da Educação. Fundo Nacional de Desenvolvimento da Educação. [Brasília: Ministério da Educação], c2017b. Disponível em: http://www.fnde.gov.br/programas/livro-didatico/livro-didatico-dadosestatisticos. Acesso em: 11 ago. 2019.

BRASIL, Ministério da Educação. Fundo Nacional de Desenvolvimento da Educação. [Brasília: Ministério da Educação], c2017c. Disponível em: http://www.fnde.gov.br/programas/livro-didatico/livro-didatico-dadosestatisticos. Acesso em: 11 ago. 2019.

BRASIL. Ministério da Educação. Secretaria de Educação Básica. Edital de convocação para inscrição no processo de avaliação e seleção de obras didáticas a serem incluídas no catálogo do programa nacional do livro para o ensino médio- PNLEM/2007. Brasília: Ministério da Educação, 2005.

BRASIL. Ministério da Educação. Edital de convocação para o processo de inscrição e avaliação de obras didáticas para o Programa Nacional Do Livro Didático PNLD 2015. Brasília: Ministério da Educação, 2013. 
BRASIL. Ministério da Educação. Secretaria de Educação Básica. FNDE. História: catálogo do Programa Nacional do Livro para o Ensino Médio: PNLEM/2008. Brasília: Ministério da Educação, 2007.

BRASIL. Ministério da Educação/SEB/FNDE. Guia de livros didáticos: PNLD2015: História: ensino médio. Brasília: Ministério da Educação, 2014.

CARVALHO, José Murilo de. A formação das almas: o imaginário da república no Brasil. São Paulo. Companhia das Letras: 1990.

CARNEIRO, Maria Angélica Lauretti. Cenografia e ethos: legitimação enunciativa em uma notícia jornalística. Alfa: Revista de Linguística, Unesp- Araraquara, v. 48, n. 2, p. 107-116, 2004. Disponível em: https://periodicos.fclar.unesp.br/alfa/article/view/4300. Acesso em: 28 ago. 2019.

COLLINS, Patricia HIll. Em direção a uma nova visão: raça, classe e gênero como categorias de análise e conexão. In: MORENO, Renata (org.). Reflexões e práticas de transformação feminista. São Paulo: SOF, 2015. 96p. (Coleção Cadernos Sempreviva. Série Economia e Feminismo).

COTRIM, Gilberto. História Global: Brasil e geral. 8. ed. São Paulo: Saraiva, 2005.

COTRIM, Gilberto. História Global: Brasil e geral. 2. ed. São Paulo: Saraiva, 2013. v. 3.

CRENSHAW, Kimberlé. A interseccionalidade na discriminação de raça e gênero, 2012. Cruzamento: raça e gênero. [S.l.]: UNIFEM, 2012. Disponível em: http://acaoeducativa.org.br/fdh/wp-content/uploads/2012/09/KimberleCrenshaw.pdf. Acesso em: 10 jun. 2020.

CRENSHAW, Kimberlé. Documento para o encontro de especialistas em aspectos da discriminação racial relativos ao gênero. Revista Estudos Feministas, Florianópolis, v. 10, n. 1, p. 175, 2002. Disponível em: https://www.scielo.br/pdf/ref/v10n1/11636.pdf. Acesso em: 04 jun. 2020.

CRENSHAW, Kimberlé. Mapeando as margens: interseccionalidade, políticas de identidade e violência contra mulheres não-brancas. Tradução de Carol Correia. Revista Subjetiva - Medium, 2017. Disponível em: https://medium.com/revistasubjetiva/mapeando-as-margens-interseccionalidade-pol\%C3\%ADticas-deidentidade-e-viol\%C3\%AAncia-contra-mulheres-n\%C3\%A3o-18324d40ad1f . Acesso em: 7 jun. 2020.

ELLSWORTH, Elizabeth. Modos de endereçamento: uma coisa de cinema, uma coisa de educação também. In: SILVA, Tomaz Tadeu da. Nunca fomos humanos: nos rastros do sujeito. Belo Horizonte: Autêntica, 2001. p. 21-53.

FONSECA, Selva. Guimarães. Didática e prática de ensino de História: experiências, reflexões e aprendizados. São Paulo: Papirus, 2003. 
GONÇALVES, Andréa Lisly. História \& gênero. Belo Horizonte: Autêntica, 2006.

JURT, Joseph. O Brasil: Um Estado-Nação a ser construído. O papel dos símbolos nacionais do Império à República. Revista Mana, Rio de Janeiro, v. 18, n.3, p. 471-509, dez. 2012. Disponível em:

http://www.scielo.br/pdf/mana/v18n3/a03v18n3.pdf. Acesso em: 2 ago. 2019.

KIMMEL, Michael. A produção simultânea de masculinidades hegemônicas e subalternas. Horizontes antropológicos, Porto Alegre, v. 4 n. 9, p. 103-117, 1998. Disponível em: http://www.scielo.br/pdf/ha/v4n9/0104-7183-ha-4-9-0103.pdf. Acesso em: 2 ago. 2019.

MACEDO, Elizabeth. A imagem da ciência: folheando um livro didático.

Educação e Sociedade, Campinas, v. 25, n. 86, p. 103-129, 2004. Disponível em: http://www.scielo.br/pdf/es/v25n86/v25n86a07. Acesso em: 2 ago. 2019.

MELO, Fernando Garcez de. Política do livro didático para o ensino médio: fundamentos e práticas. 2012. 161 f. Dissertação (Mestrado em educação) Faculdade de Educação, Universidade de Brasília, Brasília, 2012.

MUNAKATA, Kazumi. O livro didático como mercadoria. Pró-Posições, v. 23, p. 51-66, 2012. Disponível em: http://www.scielo.br/pdf/pp/v23n3/04.pdf. Acesso em: 2 ago. 2019.

MUNAKATA, Kazumi. Produzindo livros didáticos e paradidáticos. 1997. 218 f. Tese (Doutorado em História e Filosofia da Educação) - São Paulo: Pontifícia Universidade Católica de São Paulo, 1997.

PERROT, Michelle. Os excluídos da história: operários, mulheres, prisioneiros. Rio de Janeiro: Paz e Terra, 1988.

PERROT, Michelle. Mulheres públicas. Tradução Roberto Leal Ferreira. São Paulo: Fundação Editora da UNESP, 1998. 159 p.

PINTO, Céli Regina Jardim. Uma história do feminismo no Brasil. São Paulo: Ed. Fundação Perseu Abramo, 2003.

SCOTT, Joan. Gênero: uma categoria útil de análise histórica. Educação \& realidade, Porto Alegre, v. 20, n. 2, p. 71-99, jul./dez. 1995. Disponível em: https://seer.ufrgs.br/index.php/educacaoerealidade/article/view/71721. Acesso em: 3 ago. 2019.

SCOTT, Joan. Prefácio Gender and politics of history. Cadernos Pagu, Campinas: IFCH, v. 3, p. 11-27, 1994. Disponível em:

https://periodicos.sbu.unicamp.br/ojs/index.php/cadpagu/article/view/1721.

Acesso em: 3 ago. 2019. 
SCOTT, Joan. A invisibilidade da experiência. Projeto História, São Paulo, n. 16, p. 297-325, fev. 1998. Disponível em:

https://revistas.pucsp.br/index.php/revph/article/view/11183. Acesso em: 3 ago. 2019.

SILVA, Tomás Tadeu da. Documentos de identidade: uma introdução às teorias do currículo. 2. ed. Belo Horizonte: Autêntica, 2005.

SILVA, Tomás Tadeu da. Currículo e identidade social: território contestado. In: SILVA, Tomás Tadeu da (org.). Alienígenas na sala de aula: uma introdução aos estudos culturais em educação. 10. ed. Petrópolis: Vozes, 2012.

VIANNA, Cláudia Pereira; UNBEHAUM, Sandra. O gênero nas políticas públicas de educação no Brasil: 1988-2002. Caderno de Pesquisa. São Paulo, v. 34, n. 121, jan./abr. 2004. Disponível em:

http://www.scielo.br/scielo.php?script=sci_arttext\&pid=\$0100-

15742004000100005. Acesso em: 3 ago. 2019. 